\title{
Mosquitoes of north america
}




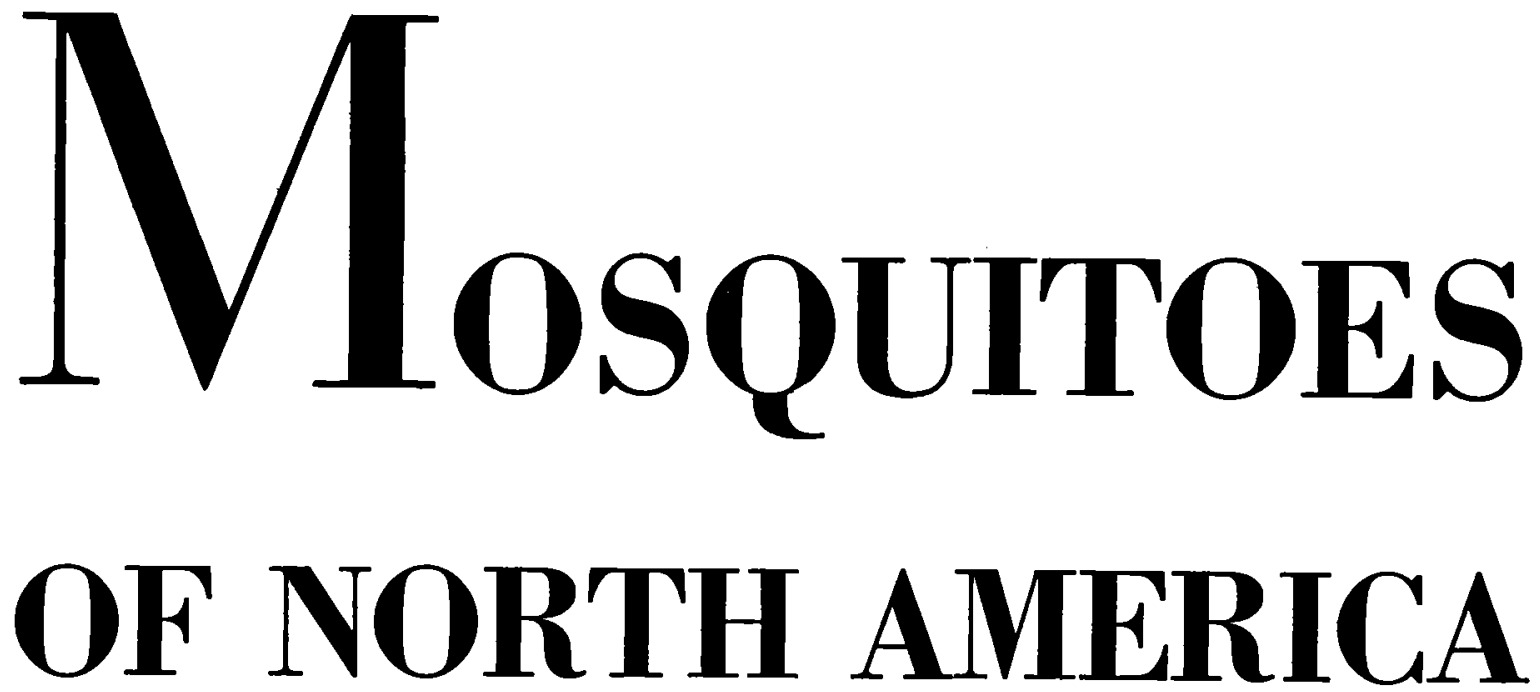

(NORTH OF MEXICO)

STANLEY J. CARPENTER and WALTER J. LaCASSE

UNIVERSITY OF CALIFORNIA PRESS - Berkeley, Los Angeles, London 
UNIVERSITY OF CALIFORNIA PRESS BERKELEY AND LOS ANGELES UNIVERSITY OF CALIFORNIA PRESS, LTD. LONDON, ENGLAND COPYRIGHT, 1955, BY

THE REGENTS OF THE UNIVERSITY OF CALIFORNIA CALIFORNIA LIBRARY REPRINT SERIES EDITION, 1974 ISBN : 0-520-02638-1

LIBRARY OF CONGRESS CATALOG CARD NUMBER: 73-93048 PRINTED IN THE UNITED STATES OF AMERICA DESIGNED BY JOHN B. GOETZ 